\title{
Características bromatológicas, fermentativas e população de leveduras de silagens de cana-de-açúcar acrescidas de ureia e aditivos absorventes de umidade
}

\author{
Jalison Lopes ${ }^{1}$, Antônio Ricardo Evangelista ${ }^{2}$ \\ ${ }^{1}$ Pós-graduação Zootecnia - UFLA. Bolsista do CNPq. \\ 2 Departamento de Zootecnia - UFLA.
}

RESUMO - Este trabalho foi conduzido com o objetivo de avaliar os efeitos da utilização de aditivos sobre as características fermentativas e bromatológicas e a população de leveduras da silagem de cana-de-açúcar. O experimento foi conduzido em delineamento inteiramente casualizado, com quatro repetições. Foram testadas diferentes quantidades de aditivos à cana-de-açúcar no momento da ensilagem (com base na matéria verde da forragem): $1,5 \%$ ureia; 0,5 ureia $+4 \%$ de milho; 0,5 ureia $+4 \%$ de mandioca desidratada; $1,5 \%$ de amireia e cana-de-açúcar controle. A cana-de-açúcar da variedade RB-72454, com 18 meses de rebrota, foi armazenada em silos experimentais de concreto com capacidade de $500 \mathrm{~kg}$ durante 180 dias. Foram avaliados os teores de matéria seca, proteína bruta, fibra em detergente neutro, fibra em detergente ácido, carboidratos não-fibrosos, cinzas, $\mathrm{pH}$, nitrogênio amoniacal e lignina e a contagem de leveduras. $\mathrm{O}$ maior teor de matéria seca e o menor teor de fibra em detergente neutro são obtidos com a associação de ureia e milho, que melhora o padrão fermentativo na silagem.

Palavras-chave: conservação de forragem, microbiologia, Saccharum sp

\section{Fermentative and bromatological characteristics and population of yeast of sugarcane silage enriched with urea and with additive absorbent of humidity}

\begin{abstract}
The research aimed to evaluate the use of additives on the fermentative and bromatological characteristics and the population of yeast of the sugarcane silage. The experiment was carried out in a complete randomized design with four replicates. It was tested different amount of additives added to the sugarcane silage at ensiling (based on the forage fresh matter) which were the following: urea $1.5 \%$; urea $0.5 \%+$ corn meal $4 \%$; urea $0.5 \%+$ dehydrated cassava $4 \%$; starea $1.5 \%$; sugar cane only. Sugarcane variety RB-72454, at 18 months of regrowth was stored for 180 days in experimental concrete silos (500 kg capacity). Contents of ash, $\mathrm{pH}$, dry matter, crude protein, neutral detergent fiber, acid detergent fiber, non fiber carbohidrate, ammonium nitrogen, lignin and count of yeasts were evaluated. The greatest contents of dry matter and the lowest contents of neutral detergent fiber are observed in the urea-corn meal treatment, which improves fermentative pattern of the silage.
\end{abstract}

Key Words: forage conservation, microbiology, Saccharum sp

\section{Introdução}

O uso da cana-de-açúcar fresca, mediante cortes diários, é tradicional e de amplo conhecimento entre pecuarsitas. Entretanto, este manejo demanda mão-deobra diária para cortes, despalha, transporte e picagem, o que pode gerar limitações operacionais quando se pretende fornecer o suplemento a rebanhos maiores.

Quando é realizada a ensilagem da cana, concentra-se a mão-de-obra em apenas um período. Outras vantagens de se colher toda a cana de uma vez são: a liberação da área antes do início das chuvas no Brasil central, possibilitando um crescimento mais uniforme da planta; o aproveitamento da cana no estádio de melhor valor nutritivo; a eliminação das sobras de cana que ficariam no campo pela falta de corte, tornando-se canas bisadas, de baixa qualidade e sujeitas ao acamamento, dificultando a colheita; possibilitar a aplicação de tratos culturais, como capina, adubações e controle com herbicidas e, ainda, em caso de incêndio acidental, poder-se-ia colher e ensilar toda a cana, evitando-se perdas no campo.

Por estas razões, a procura por informações sobre tecnologias de confecção da silagem de cana-de-açúcar, bem como seus resultados no desempenho animal tem sido 
crescente, o que justifica as pesquisas sobre o assunto. Entretanto, uma grande barreira à confecção da silagem de cana-de-açúcar é a intensa fermentação alcoólica quando a forragem é ensilada pura, em razão da grande população de leveduras naturalmente presente na cana-de-açúcar no momento da ensilagem.

Em trabalhos publicados recentemente no Brasil, há relatos de que as silagens de cana-de-açúcar tratadas com 0,5 a $1,5 \%$ de ureia apresentam bom padrão de fermentação e melhor composição bromatológica, com teor mais elevado de matéria seca e teores mais baixos de fibra em detergente ácido e fibra em detergente neutro, em comparação a silagens de cana exclusivamente (Lima et al., 2002; Molina et al., 2002).

A adição de fontes de carboidratos induz a uma redução da exigência de carboidratos solúveis, garantindo processo fermentativo satisfatório, impedindo o desenvolvimento de microrganismos indesejáveis e tornando a silagem de gramíneas tropicais um alimento de valor nutricional adequado e de baixo custo de produção (Balsalobre et al., 2001).

Objetivou-se com este estudo avaliar o efeito do uso de aditivos sobre as características fermentativas e bromatológicas e a população de leveduras da silagem de cana-de-açúcar.

\section{Material e Métodos}

O experimento foi conduzido no Departamento de Zootecnia da Universidade Federal de Lavras, Minas Gerais. Para confecção das silagens, foi utilizada cana-de-açúcar, cultivar RB-72454, com 18 meses de rebrota e cultivada em área do Departamento de Zootecnia, com rendimento de matéria verde estimado de $60 \mathrm{t} / \mathrm{h}$. Para picagem da cana, utilizou-se ensiladora mecânica, procurando-se obter partículas com tamanho médio de $2 \mathrm{~cm}$.

O processo de ensilagem teve início no dia 10/11/2004 e término no dia 12/11/2004. Foram utilizados silos experimentais cilíndricos de concreto, com capacidade aproximada de $500 \mathrm{~kg}$. A compactação do material foi feita com pisoteamento da forragem e os silos foram vedados com lona plástica, colocando-se ainda por cima da lona uma camada de aproximadamente $5 \mathrm{~cm}$ de terra. Os silos foram mantidos fechados por 180 dias.

Os aditivos utilizados no ensaio foram ureia, milho, amireia e mandioca desidratada, obtida pela picagem da raiz integral de mandioca e pela secagem até atingir nível de umidade inferior a $15 \%$.

Os seguintes aditivos foram adicionados no momento da ensilagem, em quantidade calculada com base no peso dos aditivos e no peso verde da forragem: cana-de-açúcar com $1,5 \%$ de ureia; 0,5 de ureia $+4 \%$ de milho; 0,5 de ureia $+4 \%$ de mandioca desidratada; $1,5 \%$ de amireia e cana-deaçúcar controle (Tabela 1).

No ato de abertura de cada silo experimental, os primeiros $10 \mathrm{~cm}$ retirados foram desprezados. Após a extração desta camada inicial, foram colhidas amostras das partes superior, mediana e inferior, à medida que os silos iam sendo diariamente descarregados. A silagem retirada era fornecida aos animais do ensaio de digestibilidade in vivo. De cada amostra em cada silo retirou-se uma alíquota de $50 \mathrm{~g}$, que foi imediatamente encaminhada para a determinação do $\mathrm{pH} \mathrm{e}$ outra alíquota $(100 \mathrm{~g})$ foi imediatamente encaminhada, à temperatura ambiente, para a realização da contagem de leveduras. Uma terceira alíquota (800 g) foi pré-seca em estufas a $55^{\circ} \mathrm{C}$, por 72 horas, moída em moinho tipo Willey e armazenada em potes plásticos devidamente identificados. Outra fração $(500 \mathrm{~g})$ foi congelada imediatamente para determinação do nitrogênio amoniacal, segundo Foldager (1977). Com exceção do pH, que foi determinado apenas a partir da amostra da porção superior, o valor observado de cada variável estudada foi o resultado da média aritmética das análises de amostras da porção superior, mediana e inferior de cada silo experimental.

Os teores de matéria seca e de proteína bruta foram determinados conforme métodos recomendados pela AOAC (1990). Os teores de fibra em detergente neutro e fibra em detergente ácido foram determinados segundo técnicas descritas por Goering \& Van Soest (1970). Os

Tabela 1 - Composição inicial e da cana-de-açúcar tratada com aditivos

\begin{tabular}{|c|c|c|c|c|c|}
\hline \multirow[t]{2}{*}{ Item } & \multirow{2}{*}{$\begin{array}{c}\text { Matéria seca } \\
\% \\
\text { Matéria } \\
\text { natural }\end{array}$} & Proteína bruta & $\begin{array}{c}\text { Fibra em detergente } \\
\text { neutro }\end{array}$ & $\begin{array}{c}\text { Fibra em detergente } \\
\text { ácido }\end{array}$ & Cinzas \\
\hline & & \multicolumn{4}{|c|}{$\%$ Matéria seca } \\
\hline $1,5 \%$ de ureia & 32,77 & 15,13 & 52,05 & 31,15 & 1,55 \\
\hline 0,5 ureia $+4 \%$ de milho & 33,73 & 7,46 & 51,71 & 30,34 & 1,66 \\
\hline 0,5 ureia $+4 \%$ de mandioca & 33,39 & 8,67 & 55,55 & 31,16 & 2,22 \\
\hline Média & 32,96 & 8,43 & 54,68 & 31,5 & 2,37 \\
\hline
\end{tabular}


teores de extrato etéreo e lignina foram determinados segundo metodologias descritas por Silva \& Queiroz (2002). O teor de carboidratos não-fibrosos foi calculado pela expressão: carboidratos não-fibrosos $=100-$ (fibra em detergente neutro + cinzas + proteína bruta + extrato etéreo). Estas análises foram realizadas no Laboratório de Nutrição Animal do Departamento de Zootecnia da Universidade Federal de Lavras.

Para contagem de leveduras, as amostras foram submetidas a diluições decimais seriadas; $25 \mathrm{~g}$ de amostra de silagem de cana-de-açúcar foram misturados em $225 \mathrm{~mL}$ de água peptonada $0,1 \%$ estéril e homogeneizados até a formação de uma suspensão. De cada amostra, $100 \mu \mathrm{L}$ da suspensão foram colocados em tubos eppendorf, com $900 \mu \mathrm{L}$ de água peptonada $0,1 \%$. Alíquotas de $0,1 \mathrm{~mL}$ foram espalhadas em placas de petri, para posterior contagem do número total de leveduras, utilizando-se o meio de cultura YEPG (extrato de levedura - $10 \mathrm{~g}$; peptona - $20 \mathrm{~g}$; glicose $20 \mathrm{~g}$; agar-ágar - $15 \mathrm{~g}$; água destilada - $1000 \mathrm{~mL}$ ), ajustando-se o pH para 3,5, com adição de antibióticos (ampicilina $1 \mathrm{~mL} \times 500 \mathrm{~mL}^{-1}$ de meio de cultura e gentamicina $357 \mu \mathrm{L} \times$ $500 \mathrm{~mL}^{-1}$ de meio de cultura) (Bravo-Martins et al., 2006).

Após a inoculação, as placas de petri foram incubadas, em posição invertida, em incubadora com temperatura controlada a $28^{\circ} \mathrm{C}$, por 48 horas, para posterior contagem das unidades formadoras de colônia (ufc). Esta análise foi realizada no Laboratório de Fisiologia de Microrganismos do Departamento de Biologia da Universidade Federal de Lavras.

O delineamento experimental utilizado foi o inteiramente casualizado, com o uso dos aditivos: $1,5 \%$ de ureia; 0,5 de ureia $+4 \%$ de milho; 0,5 de ureia $+4 \%$ de mandioca desidratada; $1,5 \%$ de amireia e um controle sem aditivos e com quatro repetições. A parcela experimental foi constituída pelo silo de concreto, com capacidade aproximada de $500 \mathrm{~kg}$, totalizando 20 parcelas experimentais.

Os dados obtidos foram analisados estatisticamente pelos procedimentos de análise de variância, por meio do programa estatístico SISVAR (Ferreira, 2000). Para efeito de comparação de médias entre tratamentos, utilizou-se o teste Tukey, a $5 \%$ de probabilidade.

\section{Resultados e Discussão}

Os teores de matéria seca, proteína bruta e carboidratos não-fibrosos da silagem foram influenciados pelos aditivos $(\mathrm{P}<0,05)$, no entanto, não se observou efeito da aplicação desses aditivos sobre o teor de cinzas $(\mathrm{P}>0,05)$ (Tabela 2$)$.

A silagem com 0,5 de ureia $+4 \%$ de milho apresentou teor de matéria seca superior ao da silagem controle, o que, certamente, é resultado da maior efetividade do aditivo em reduzir as perdas ocorridas durante todo o processo fermentativo neste tratamento. O menor valor observado na silagem de cana-de-açúcar controle provavelmente é resultado da maior produção de gases e efluentes oriundos da maior extensão de fermentações indesejáveis, decorrente principalmente da ação de leveduras.

$\mathrm{Na}$ literatura os teores de matéria seca de silagens de cana-de-açúcar são semelhantes aos de silagem contendo 0,5 de ureia $+4 \%$ de milho, porém com tempo de armazenamento bem inferior. Bernardes et al. (2007) observaram teor de matéria seca de $27,2 \%$ após 55 dias de ensilagem. Evangelista et al. (2009), no entanto observaram redução no teor de matéria seca de $36,4 \%$ (matéria original) para $27,0 \%$ respectivamente para 0 e 68 dias de ensilagem, ambos em silagens com $10 \%$ de milho desintegrado com palha e sabugo.

A redução de matéria seca está relacionada à diminuição de conteúdo celular, principalmente de carboidratos solúveis, durante o processo fermentativo (Woolford, 1984). McDonald et al. (1991) relata que outras vias comuns de perdas de matéria seca são a produção de efluentes e a perda por água resultante de reações metabólicas. Ainda, conforme esses autores, a produção de etanol pelas leveduras é acompanhada pela perda acentuada de matéria seca dos substratos na forma de $\mathrm{CO}_{2}$ e $\mathrm{H}_{2} \mathrm{O}$. Assim, os resultados

Tabela 2 - Teores de matéria seca, proteína bruta, carboidratos não-fibrosos e cinzas de silagens de cana-de-açúcar tratadas com aditivos

\begin{tabular}{|c|c|c|c|c|}
\hline \multirow[t]{2}{*}{ Item } & \multirow{2}{*}{$\begin{array}{c}\text { Matéria seca } \\
\% \mathrm{MN} \\
\end{array}$} & Proteína bruta & Carboidratos não-fibrosos & Cinzas \\
\hline & & \multicolumn{3}{|c|}{$\% \mathrm{MS}$} \\
\hline $1,5 \%$ de ureia & $24,91 \mathrm{ab}$ & $12,33 \mathrm{a}$ & $8,08 \mathrm{~b}$ & 3,88 \\
\hline 0,5 de ureia $+4 \%$ de mandioca & $24,94 \mathrm{ab}$ & $6,90 b$ & $16,30 \mathrm{a}$ & 4,16 \\
\hline $1,5 \%$ de amireia & $24,99 \mathrm{ab}$ & $10,30 \mathrm{a}$ & $16,39 a$ & 4,41 \\
\hline Cana-de-açúcar controle & $23,18 b$ & $4,88 \mathrm{~b}$ & $14,9 \mathrm{ab}$ & 4,86 \\
\hline
\end{tabular}

Médias seguidas de letras iguais na coluna não diferem $(\mathrm{P}>0,05)$ pelo teste Tukey.

CV - coeficiente de variação; MN - matéria natural; MS - matéria seca. 
observados para os teores de matéria seca neste estudo estão de acordo com os obtidos por McDonald et al. (1991), visto que, no caso específico de silagens de cana-de-açúcar, devido à elevada população de leveduras naturalmente encontradas no material, no início do processo de ensilagem, as perdas de matéria seca provocadas pelo metabolismo desses microrganismos podem tornar-se bastante significativas.

Os maiores teores de proteína bruta foram observados com a aplicação de 1,5\% de ureia e 1,5\% de amireia. Esta elevação deve-se ao maior teor de nitrogênio não-protéico adicionado por meio destes aditivos, já que a ureia é um aditivo rico em nitrogênio ( $45 \%$ ) e a amireia utilizada neste ensaio apresenta em torno de $64 \%$ de ureia. O aumento no teor de proteína bruta da silagem de cana-de-açúcar controle em relação à cana fresca sem aditivo (Tabela 1) está associado à concentração deste nutriente na matéria seca, principalmente como consequência da perda de carboidratos solúveis por respiração no processo de fermentação da silagem. O teor de proteína bruta pode sofrer aumento de $1 \%$ a $2 \%$ na matéria seca, devido a este processo (Rotz \& Muck, 1994).

A aplicação de $1,5 \%$ de ureia na cana-de-açúcar no momento da ensilagem proporcionou teor de proteína bruta superior aos 7,7\% observados por Lima et al. (2002), mas inferior aos 13,9\% encontrados por Siqueira et al. (2007a), também em silagens de cana-de-açúcar com 60 dias de armazenamento e mesma proporção deste aditivo.

Os teores de carboidratos não-fibrosos das silagens com aditivos não diferiram do obtido na silagem de cana pura. Entretanto, se analisadas apenas as silagens com aditivos, nota-se que a silagem com $1,5 \%$ de ureia foi inferior às demais. Essa superioridade das outras silagens de ureia ocorreu pelo fato de que o fubá, a mandioca desidratada e a amireia são fontes de carboidratos não-fibrosos. O menor teor de carboidratos não-fibrosos observado com a adição de $1,5 \%$ de ureia pode ser explicado pela forma como este parâmetro é calculado. No cálculo do carboidratos nãofibrosos, a fração proteína bruta é descontada e calculada pela multiplicação do teor de nitrogênio da amostra pelo fator 6,25. Por este motivo, com a adição de ureia, que é uma fonte de nitrogênio não-protéico, o teor de carboidratos não-fibrosos em silagens que contenham este aditivo fica subestimado, o que explica o menor valor encontrado na silagem com o mais alto nível de ureia.

A cana-de-açúcar possui duas frações predominantes em sua constituição, carboidratos não-fibrosos e fibra em detergente neutro, que representam cerca de $90 \%$ da constituição desta forragem e a avaliação pelo teor de carboidratos não-fibrosos não deve ser associada diretamente aos carboidratos solúveis, pois, nos carboidratos não-fibrosos, computa-se a presença de outros compostos, como ácidos orgânicos (Siqueira et al., 2007a). No entanto, considerando que, na cana-de-açúcar, as leveduras são os principais microrganismos capazes de fermentar os carboidratos solúveis contidos na fração de carboidratos não-fibrosos, possivelmente com maior inibição da atividade dessas leveduras, o conteúdo de carboidratos solúveis residuais será maior na silagem e, consequentemente, também será maior o teor de carboidratos não-fibrosos.

Os teores de cinzas não variaram significativamente e o valor foi médio de $4,26 \%$ após a abertura dos silos. Ocorreu aumento em relação ao material original (Tabela 1), em decorrência das perdas de constituintes celulares durante a fermentação, resultando em elevação proporcional nos valores.

Os aditivos tiveram efeito sobre os teores de fibra em detergente neutro, fibra em detergente ácido e hemicelulose das silagens $(\mathrm{P}<0,05)$, porém, o teor de lignina não foi afetado pelos aditivos utilizados $(\mathrm{P}>0,05)$ (Tabela 3 ).

Três fatores podem ter contribuído para o menor teor de fibra em detergente neutro observado na silagem com aditivo 0,5 de ureia $+4 \%$ de milho em relação à silagem de cana pura. Um deles é a maior preservação do aditivo (milho) ao longo do processo fermentativo e, como no milho o teor de fibra em detergente neutro é mais baixo que na cana-de-açúcar, houve menor aporte deste componente nessa silagem. Associa-se a esta preservação do aditivo a ação da ureia sobre os constituintes celulares, solubilizando, principalmente a hemicelulose. Como a hemicelulose é um dos componentes da parede celular, sua solubilização implica redução da fibra em detergente neutro. Ainda, a maior redução no teor de matéria seca observada na silagem de cana controle em relação à silagem com o aditivo 0,5 de ureia $+4 \%$ de milho também contribuiu para maior concentração desta fração.

A cana-de-açúcar utilizada neste experimento encontrava-se com elevado teor de fibra em detergente neutro (Tabela 1), devido ao seu avançado estádio de maturação (18 meses), o que também contribuiu para o alto teor de fibra em detergente neutro observado na abertura do silo. $\mathrm{O}$ teor de fibra em detergente neutro na silagem com 0,5 de ureia $+4 \%$ de milho foi próximo aos $61,75 \%$ observados por Silva et al. (2003) em silagem de canacom $8 \%$ de fubá na matéria natural com aditivo enzimo-bacteriano, após 45 dias de ensilagem.

$\mathrm{Na}$ literatura também são citados teores de fibra em detergente neutro elevados em silagem de cana pura colhida em estádios vegetativos mais avançados. Santos et al. (2006) 
observaram teor de $70,36 \%$ de fibra em detergente neutro (na matéria seca), em cana-de-açúcar ensilada com 24 meses. Roth et al. (2005) observaram teor de fibra em detergente neutro de $75 \%$ da matéria seca na cana ensilada aos 15 meses. Evangelista et al. (2009), no entanto, avaliaram o perfil de fermentação na ensilagem da cana-de-açúcar pura, observaram elevação do teor de fibra em detergente neutro de 55,6\% para $75,6 \%$, aos 50 dias de fermentação.

Conforme relatos de McDonald et al. (1991), a elevação no teor de fibra em detergente neutro é relativa e ocorre devido à perda de conteúdo celular no período de fermentação. Silagens de cana-de-açúcar confeccionadas sem aditivos frequentemente resultam em materiais com elevados teores de fibra, devido à ausência de inibição de leveduras, que são os maiores responsáveis pela redução do conteúdo celular nessas silagens. É interessante que as silagens apresentem baixos teores de fibra em detergente neutro, por sua correlação inversa com a ingestão de matéria seca (Van Soest, 1982).

Os teores de fibra em detergente ácido das silagens com aditivos não diferiram dos obtidos na silagem controle. Houve diferença apenas entre as silagens com $1,5 \%$ de ureia e 0,5 de ureia $+4 \%$ de milho. Siqueira et al. (2007a) observaram teor de $45,8 \%$ de fibra em detergente ácido na matéria seca da cana-de-açúcar aditivada com $1,5 \%$ de ureia após 60 dias de ensilagem. O valor observado nesta pesquisa foi semelhante, com a mesma proporção do aditivo. Roth et al. (2005) observaram maior concentração nos teores de fibra em detergente ácido com a adição de ureia em níveis de 48,$7 ; 53,8 ; 52,0$ e 52,5\% da matéria seca, respectivamente, para as doses de 0,$5 ; 1,0 \mathrm{e}$ $2 \%$ de ureia na MV da cana ensilada. Menores teores de fibra em detergente ácido caracterizam silagens de melhor qualidade, pois este componente da parede celular é inversamente correlacionado à digestibilidade da matéria seca (Mertens, 1982).

Os teores de hemicelulose de todas as silagens com aditivos reduziram em relação à silagem de cana controle, comprovando a grande capacidade de solubilização da fração fibrosa decorrente do uso de ureia. A hemicelulose é um parâmetro importante na avaliação da fermentação da silagem de cana. McDonald (1991), avaliando diversas silagens, verificou que, quando os carboidratos solúveis se esgotam, a hemicelulose pode servir de substrato para as bactérias fermentadoras. Essa disponibilização extra de substrato, aliada à comprovada capacidade inibitória da amônia sobre as leveduras, pode garantir maior colonização do material por bactérias ácido-láticas, resultando em um produto final de melhor qualidade.

Não houve efeito dos aditivos sobre o teor de lignina, cujo valor médio foi de $12,8 \%$ da matéria seca. Possivelmente, a maior complexidade entre as ligações das moléculas que compõem esta fração dificulta sua solubilização pela ureia. Roth et al. (2005) também não observaram efeito da inclusão de quantidades crescentes de ureia $(0 \%$ a $2 \%$ da matéria verde) na ensilagem de cana-de-açúcar sobre os teores de lignina. Na literatura é amplamente discutida a inconsistência do efeito da ureia sobre a fração lignina (Reis et al., 1990).

Maior preservação de conteúdo celular resulta em menor concentração da fração fibrosa, pois implica em menores perdas de carboidratos não-fibrosos. É possível associar a elevação da fibra em detergente neutro à recuperação de matéria seca, já que silagens com os maiores teores de fibra em detergente neutro apresentaram as menores recuperações de matéria seca (Siqueira, 2005).

A inclusão dos aditivos influenciou o valor de $\mathrm{pH}$, nitrogênio amoniacal e contagem de leveduras das silagens $(\mathrm{P}<0,05)$ (Tabela 4).

A silagem com $1,5 \%$ de ureia apresentou $\mathrm{pH}$ superior à silagem de cana-de-açúcar controle. Possivelmente, o retardo na queda do $\mathrm{pH}$, em função da maior quantidade de ureia utilizada neste tratamento, conseqüentemente produzindo mais hidróxido de amônio, interferiu na extensão da colonização da massa ensilada pelas bactérias ácido láticas, favorecendo o crescimento de microrganismos indesejáveis que atuam em faixas de $\mathrm{pH}$ mais alto. Acrescenta-se, ainda,

Tabela 3 - Teores de fibra em detergente neutro, fibra em detergente ácido, hemicelulose e lignina de silagens de cana tratadas com aditivos

\begin{tabular}{|c|c|c|c|c|}
\hline \multirow[t]{2}{*}{ Item } & Fibra em detergente neutro & Fibra em detergente ácido & Hemicelulose & Lignina \\
\hline & \multicolumn{4}{|c|}{$\%$ Matéria seca } \\
\hline $1,5 \%$ de ureia & $68,19 \mathrm{ab}$ & $45,78 \mathrm{a}$ & $22,41 b$ & 13,95 \\
\hline 0,5 ureia $+4 \%$ de milho & $63,55 b$ & $39,38 b$ & $24,17 b$ & 11,54 \\
\hline 0,5 ureia $+4 \%$ de mandioca & $67,56 \mathrm{ab}$ & $41,59 \mathrm{ab}$ & $25,96 b$ & 11,49 \\
\hline $1,5 \%$ de amireia & $65,02 \mathrm{ab}$ & $41,02 \mathrm{ab}$ & $24,00 \mathrm{~b}$ & 12,28 \\
\hline Cana-de-açúcar controle & $71,77 \mathrm{a}$ & $41,52 \mathrm{ab}$ & $30,25 \mathrm{a}$ & 11,89 \\
\hline Média & 67,22 & 41,86 & 25,36 & 12,18 \\
\hline CV $(\%)$ & 5,29 & 6,01 & 7,61 & 12,10 \\
\hline
\end{tabular}

Médias seguidas de letras iguais na coluna não diferem $(\mathrm{P}>0,05)$ pelo teste Tukey.

CV - coeficiente de variação 
que a silagem com $1,5 \%$ de ureia foi a que apresentou as piores características sensoriais no momento de abertura dos silos (cor escura e forte cheiro de amônia).

As demais silagens apresentaram $\mathrm{pH}$ dentro da faixa ideal, entre 3,8 e 4,2 (McDonald et al., 1991).

O valor de $\mathrm{pH}$ de 6,48 observado com o maior uso de ureia neste experimento foi bem maior que os valores observados na literatura. Para mesma proporção deste aditivo, foram encontrados pH de 4,2 (Siqueira et al., 2007b) e 3,75 (Lima et al., 2002) em silagens de cana-de-açúcar com 60 dias de armazenamento. Pedroso et al. (2007) observaram pH de 3,83 na média das observações feitas aos 90 e 180 dias de ensilagem da cana-de-açúcar com 1,5\% de ureia, o que comprova que o valor encontrado neste trabalho foi alto, mesmo quando comparado a um estudo com período semelhante de estocagem do material. A transformação da ureia em hidróxido de amônio, uma substância alcalinizante, não é um processo instantâneo (Siqueira, 2005). Em estudos de Pedroso (2003), silagens tratadas com $0,5 \%$ de ureia levaram 20 dias para atingir $\mathrm{pH}$ inferior a 4, enquanto em silagens sem ureia, este período foi de apenas dez dias. Com base nesta diferença, o autor supôs que enterobactérias e clostrídeos tiveram seu período de desenvolvimento prolongado, devido ao atraso na queda do $\mathrm{pH}$ da silagem, provocado pelo poder tamponante da ureia, levando a maior perda total de matéria seca. Possivelmente, esta situação verificada por Pedroso (2003) também ocorreu neste estudo na silagem tratada com $1,5 \%$ de ureia.

A velocidade de queda do $\mathrm{pH}$ é mais importante que o pH final, pois é diretamente proporcional à diminuição da ação de microrganismos indesejáveis no ambiente do silo e, isoladamente não é suficiente para impedir o desenvolvimento de leveduras, pois o ácido lático tem baixo poder fungicida (McDonald et al., 1991).

$\mathrm{O}$ valor de nitrogênio amoniacal foi maior na silagem com $1,5 \%$ de ureia, em relação à silagem de cana controle,

Tabela 4 - Valores de $\mathrm{pH}$, nitrogênio amoniacal e população de leveduras de silagens de cana tratadas com aditivos

\begin{tabular}{lccc}
\hline Item & $\mathrm{pH}$ & $\begin{array}{c}\text { Nitrogênio } \\
\text { amoniacal }\end{array}$ & Leveduras \\
\cline { 2 - 4 } & & $\begin{array}{c}\text { \% nitrogênio } \\
\text { total }\end{array}$ & $\begin{array}{c}\text { Log de } \\
\text { ufc/g MV }\end{array}$ \\
\hline $1,5 \%$ de ureia & $6,48 \mathrm{a}$ & $36,68 \mathrm{a}$ & $4,24 \mathrm{~b}$ \\
0,5 ureia $+4 \%$ de milho & $3,53 \mathrm{~b}$ & $4,48 \mathrm{~d}$ & $4,34 \mathrm{~b}$ \\
0,5 ureia $+4 \%$ de mandioca & $3,96 \mathrm{~b}$ & $8,73 \mathrm{c}$ & $5,60 \mathrm{a}$ \\
$1,5 \%$ de amireia & $4,18 \mathrm{~b}$ & $16,10 \mathrm{~b}$ & $4,65 \mathrm{~b}$ \\
Cana-de-açúcar controle & $3,76 \mathrm{~b}$ & $2,06 \mathrm{~d}$ & $5,41 \mathrm{a}$ \\
Média & 4,38 & 13,61 & 4,86 \\
CV $(\%)$ & 8,15 & 13,83 & 5,09 \\
\hline
\end{tabular}

Médias seguidas de letras iguais na coluna não diferem $(\mathrm{P}>0,05)$ pelo teste Tukey $\mathrm{CV}$ - coeficiente de variação. o que pode ser explicado pela maior presença de nitrogênio não-protéico com o uso deste aditivo. A maior quantidade de nitrogênio amoniacal na silagem com $1,5 \%$ de ureia explica o pH no momento de abertura do silo, pois a elevação na concentração de amônia com a adição de ureia, verificada por meio do maior teor de nitrogênio amoniacal, pode provocar maior $\mathrm{pH}$ final da silagem. Entre as silagens com aditivos, o menor valor de nitrogênio amoniacal foi observado na silagem com 0,5 de ureia $+4 \%$ de milho, o que indica menor atividade microbiana durante o período de estocagem do material. Siqueira (2005) observou valores de nitrogênio amoniacal de 2,9 e 14,7\%, respectivamente, para cana ensilada pura e aditiva com $1,5 \%$ de ureia após 60 dias de ensilagem. Lima et al. (2002), no entanto, observaram valores de nitrogênio amoniacal de 3,39 e 11,84\%, respectivamente, para a cana ensilada sem aditivos e acrescida de ureia ( $1,5 \%$ da MV).

Os valores de nitrogênio amoniacal sugeridos para silagens de bom padrão fermentativo estão, no máximo, entre 11 e $12 \%$. No entanto, silagens com ureia, frequentemente, apresentam maiores valores de nitrogênio amoniacal e a avaliação do valor nutritivo destas silagens deve ser feita com mais critério (Silveira, 1975).

O nitrogênio amoniacal é associado à qualidade fermentativa da silagem, pois é proveniente da degradação da fração protéica pelos clostrídeos (McDonald et al., 1991). Contudo, na ensilagem da cana-de-açúcar, espera-se que essa degradação seja inibida pela rápida queda do $\mathrm{pH}$, decorrente do baixo poder tampão e a presença abundante de carboidratos solúveis. É importante salientar que a amônia originada da ação da urease sobre a ureia funciona como inibidor do crescimento de leveduras, o que pode refletir em menores perdas.

A maior inibição do crescimento de leveduras nas silagens foi maior com $1,5 \%$ de ureia, 0,5 de ureia $+4 \%$ de milho e $1,5 \%$ de amireia em relação a silagem de cana-deaçúcar controle. Esperava-se que a associação da ureia com a mandioca desidratada também fosse capaz de inibir o desenvolvimento de leveduras, já que, além do possível efeito inibidor da ureia, a elevação nos teores de matéria seca, com a introdução de aditivos absorventes como a mandioca desidratada também poderia reduzir o crescimento de leveduras, pelo fato de favorecer o crescimento de populações de bactérias ácido -láticas heterofermentativas, produtoras de ácido lático e acético em detrimento ao crescimento das bactérias ácido- láticas homofermentativas, capazes de produzir apenas ácido lático. Sabidamente, ao contrário do ácido lático, o ácido acético é um potente inibidor do crescimento de leveduras. Entretanto, esta hipótese não foi confirmada. 
Uma das explicações para justificar a ausência de efeito do uso da mandioca desidratada sobre a inibição do crescimento de leveduras poderia ser a diferença do amido da mandioca em relação ao amido do milho. Segundo Simas et al. (2008), uma das características do amido de mandioca que o diferenciam do milho é a ausência de matriz proteica e de corpos proteicos associados aos grãos de amido, o que confere ao amido da raspa de mandioca maior degradabilidade ruminal em relação ao amido do milho (NRC, 2001). Provavelmente, esta maior facilidade de ataque microbiano também foi verificada durante a ensilagem e pode ter contribuído para a maior proliferação de leveduras. O efeito do aditivo absorvente na inibição do crescimento de leveduras possivelmente está associado ao nível e ao tipo de amido presente no aditivo utilizado.

\section{Conclusões}

Entre os aditivos avaliados (ureia, amireia, milho e mandioca desidratada), o aditivo composto de 0,5 de ureia $+4 \%$ de milho proporciona resultados mais positivos na qualidade da silagem de cana-de-açúcar.

\section{Referências}

ASSOCIATION OF OFFICIAL ANALYTICAL CHEMISTS AOAC. Official methods of analysis of the Association of Analytical Chemists. 15.ed. Arlington, 1990. v.1, 1117p.

BALSALOBRE, M.A.A.; NUSSIO, L.G.; MARTHA JR., G.B. Controle de perdas na produção de silagens de gramíneas tropicais. In: MATTOS, W.R.S. (Ed.) A produção animal na visão dos brasileiros. Piracicaba: Fundação de Estudos Agrários Luiz de Queiroz, 2001. p.890-911.

BERNARDES, T.F.; REIS, R.A.; SIQUEIRA, G.R. et al. Avaliação da queima e da adição de milho desintegrado com palha e sabugo na ensilagem de cana-de-açúcar. Revista Brasileira de Zootecnia, v.36, n.2, p.269-275, 2007.

BRAVO-MARTINS, C.E.C.; CARNEIRO, H.; CASTRO-GÓMEZ, R.J.H. et al. Chemical and microbiological evaluation of ensiled sugar cane with different additives. Brazilian Journal of Microbiology, v.37, p.499-504, 2006.

EVANGELISTA, A.R.; SIQUEIRA, G.R.; LIMA, J.A. et al. Alterações bromatológicas e fermentativas durante o armazenamento de silagens de cana-de-açúcar com e sem milho desintegrado com palha e sabugo. Revista Brasileira de Zootecnia, v.38, n.1, p.20-26, 2009.

FERREIRA, D.F. Análises estatísticas por meio do Sisvar para Windows versão 4.0. In: REUNIÃO ANUAL DA REGIÃO BRASILEIRA DA SOCIEDADE INTERNACIONAL DE BIOMETRia, 45., 2000, São Carlos. Anais... São Carlos: UFSCAR, 2000. p.255-258.

FOLDAGER, J. Protein requeriment and non protein nitrogen for high producing cow in early lactation. 1977. 182f. Thesis (Ph.D.) - Michigan State University, East Lansing.

GOERING, H.K.; VAN SOEST, P.J. Forage fiber analysis (apparatus reagents, procedures and some applications). Washington: USDA, 1970. 379p. (Agricultural Research Service. Handbook).
LIMA, J.A.; EVANGELISTA, A.R.; ABREU, J.G. et al. Silagem de cana-de-açúcar (Saccharum officinarum L.) enriquecida com ureia ou farelo de soja. In: REUNIÃO ANUAL DA SOCIEDADE BRASILEIRA DE ZOOTECNIA, 39., 2002, Recife. Anais... Recife: Sociedade Brasileira de Zootecnia, 2002. (CD-ROM).

McDONALD, P.; HENDERSON, A.R.; HERON, S.J.E. The biochemistry of silage. 2.ed. Merlow: Chalcomb Publications, 1991. 340p.

MERTENS, D.R. Using neutral detergent fiber to formulate dairy rations. In: NUTRITION CONFERENCE PROCESS GANT CONFERENCE FOR THE FEED INDUSTRY, 1982, Athens. Proceedings... Athens: University of Georgia, 1982. p.116-126.

MOLINA, L.R.; FERREIRA, D.A.; GONÇALVES, L.C. et al. Padrão de fermentação da silagem de cana-de-açúcar submetida a diferentes tratamentos. In: REUNIÃO ANUAL DA SOCIEDADE BRASILEIRA DE ZOOTECNIA, 39., 2002, Recife. Anais... Recife: Sociedade Brasileira de Zootecnia, 2002. (CD-ROM).

NATIONAL RESEARCH COUNCIL. Nutrient requirements of dairy catlle. 7.ed. Washington, D.C.: National Academic Press, 2001. 381p.

PEDROSO, A.F. Aditivos químicos e microbianos no controle de perdas e na qualidade de silagem de cana-de-açúcar (Saccharum officinarum L.). Piracicaba, 2003. 122f. Tese (Doutorado em Agronomia) - Escola Superior de Agricultura "Luiz de Queiroz"/Universidade de São Paulo, Piracicaba.

PEDROSO, A.F.; NUSSIO, L.G.; LOURES, D.R.S. et al. Efeito do tratamento com aditivos químicos e inoculantes bacterianos nas perdas e na qualidade de silagens de cana-de-açúcar. Revista Brasileira de Zootecnia, v.36, n.3, p.558-564, 2007.

REIS, R.A.; GARCIA, R.; SILVA, D. J. Efeito da aplicação de amônia anidra sobre a composição química e digestibilidade in vitro de fenos de três gramíneas tropicais. Revista Brasileira de Zootecnia, v.19, n.3, p.219-224, 1990.

ROTH, M.T.P.; SIQUEIRA, G.R.; RICARDO, R.A. et al. Ensilagem da cana-de-açúcar ("Saccharum officinarum"L.) tratada com doses de ureia. In: REUNIÃO ANUAL DA SOCIEDADE BRASILEIRA DE ZOOTECNIA, 42., 2005, Goiânia. Anais... Goiânia: Sociedade Brasileira de Zootecnia, 2005. (CD-ROM).

ROTZ, C.A.; MUCK, R.E. Changes in forage quality during harvest and storage. In: Forage quality, evaluation and utilization. Madison: ASA; CSSA; SSSA, 1994. p.828-868.

SANTOS, R.V.; EVANGELISTA, A.R.; PINTO, J.C. et al. Composição química da cana-de-açúcar (Saccharum spp.) e das silagens com diferentes aditivos em duas idades de corte. Ciência e Agrotecnologia, v.30, n.6, p.1184-1189, 2006.

SIMAS, J.M.C.; PIRES, A.V.; SUSIN, I. et al. Efeitos de fontes e formas de processamento do amido na utilização de nutrientes e parâmetros ruminais de vacas em lactação. Arquivo Brasileiro de Medicina Veterinária e Zootecnia, v.60, n.5, p.1128-1134, 2008

SILVA, D.J.; QUEIROZ, A.C. Análise de alimentos: métodos químicos e biológicos. 3.ed. Viçosa, MG: UFV, Imprensa Universitária, 2002. 235p.

SILVA, S.A.R.; ROSA, B.; REIS, R.A. et al. Composição química da cana-de-açúcar ensilada com diferentes aditivos. In: REUNIÃO ANUAL DA SOCIEDADE BRASILEIRA DE ZOOTECNIA, 40., 2003, Santa Maria. Anais... Santa Maria: Sociedade Brasileira de Zootecnia, 2003. (CD-ROM).

SILVEIRA, A.C. Técnicas para produção de silagens. In: SIMPÓSIO SOBRE MANEJO DE PASTAGENS, 2., 1975, Piracicaba. Anais... Piracicaba: Escola Superior de Agricultura "Luiz de Queiroz”, 1975. p.156-180.

SIQUEIRA, G.R. Cana-de-açúcar (Saccharum officinarum L.) ensilada com aditivos químicos e bacterianos. 2005. $91 \mathrm{f}$. Dissertação (Mestrado em Zootecnia)/Universidade Estadual Paulista, Jaboticabal. 
SIQUEIRA, G.R.; REIS, R.A.; SCHOCKEN-ITURRINO, R.P. et al. Associação entre aditivos químicos e bacterianos na ensilagem de cana-de-açúcar. Revista Brasileira de Zootecnia, v.36, n.4, p.789-798, 2007a.

SIQUEIRA, G.R.; REIS, R,A.; SCHOCKEN-ITURRINO, R.P. et al. Perdas de silagens de cana-de-açúcar tratadas com aditivos químicos e bacterianos. Revista Brasileira de Zootecnia, v.36, n.6, p.2000-2009, 2007b (supl.).

VAN SOEST, P.J. Nutritional ecology of the ruminants. Corvallis: O \& Books, 1982. 373p.

WOOLFORD, M.K. The silage fermentation. New York: Marcel Dekker, 1984. 350p. 